UDC 666.291

Ts.I. Dimitrov ${ }^{a}$, R.H. Titorenkova ${ }^{b}$, A.V. Zaichuk ${ }^{c}$, Y.K. Tzvetanova ${ }^{b}$

\title{
SYNTHESIS AND STUDY OF FERRI-DIOPSIDE CERAMIC PIGMENTS
}

\author{
${ }^{a}$ University of Ruse «Angel Kanchev», Branch Razgrad, Bulgaria \\ b Institute of Mineralogy and Crystallography «Acad. I. Kostov», Bulgarian Academy of Sciences, \\ Sofia, Bulgaria \\ ${ }^{c}$ Ukrainian State University of Chemical Technology, Dnipro, Ukraine
}

\begin{abstract}
The article reports the mineralogical composition, structural features and changes in color parameters of iron-containing diopside pigments. The source of $\mathrm{SiO}_{2}$ in these pigments was $\mathrm{SiO}_{2} \cdot \mathrm{nH}_{2} \mathrm{O}$ with a particle size in the range of $2-7 \mu \mathrm{m}$, which is much more reactive than conventionally used quartz sand. A series of ceramic pigments on the basis of stoichiometric diopside in the system $\mathrm{CaO}-\mathrm{Fe}_{2} \mathrm{O}_{3}-\mathrm{MgO}-\mathrm{SiO}_{2}$ was synthesized via solidstate high temperature sintering at 1000,1100 and $1200^{\circ} \mathrm{C}$. The resulting ceramic pigments were examined by powder X-ray diffraction, infrared spectroscopy, electron microscopy, electron paramagnetic resonance and Mössbauer spectroscopy. The color characteristics were measured using spectrophotometry method. It was found that multiphase ceramic pigments were obtained under the synthesis conditions, which contain diopside, wollastonite, cristobalite, akermanite and periclase in various proportions. The synthesized ceramic pigments are brown and beige in color, depending on the content of $\mathrm{Fe}_{2} \mathrm{O}_{3}$ additive, firing temperature and phase composition. The synthesized pigments can be used for staining of ceramic glazes.
\end{abstract}

Keywords: ceramic pigments, diopside, mineral composition, colorimetric indices, synthesis.

DOI: $10.32434 / 0321-4095-2022-140-1-39-46$

\section{Introduction}

The ceramic pigments exhibit high corrosion resistance to the high-temperature action of glass melts of various natures, which makes it possible to achieve almost any color gamut of glass coatings [1].

The ceramic pigments are mainly obtained by the method of solid-phase synthesis from chemically pure reagents or natural raw materials [2,3]. Numerous studies have also been carried out [4-7] aimed at the effective use of various industrial wastes in the technology of ceramic pigments. At the same time, the synthesis of ceramic pigments, as a rule, is performed at high temperatures and requires the introduction of mineralizing additives [1].

The ceramic pigments of various silicate structures often require less energy consumption for the synthesis process due to the peculiarities of their structure, and also allow achieving a wide color palette [8-10].

The choice of a pyroxene matrix for ceramic pigments in this study is determined by that the synthesis of diopside can be carried out at relatively low temperatures without using mineralizers. In this case, a stable color is formed, which depends on the nature of the introduced chromophore [11].

The color of the most natural and synthetic minerals is associated with the presence of transitional metals incorporated in the crystal structure, which have an unfilled d- or f-electron orbital determining the electronic transition under the action of light energy [1]. The crystal structure of diopside is monoclinic, space group $\mathrm{C} 2 / \mathrm{c}$. The pyroxene structure consists of single chains of tetrahedra extending parallel to c axis. Two types of cation positions are denoted as $\mathrm{M} 1$ and $\mathrm{M} 2$. The general formula of pyroxenes is $\mathrm{M}_{2} \mathrm{M}_{1} \mathrm{~T}_{2} \mathrm{O}_{6}$. The following cations, $\mathrm{Mg}^{2+}, \mathrm{Fe}^{2+}, \mathrm{Ca}^{2+}, \mathrm{Li}^{+}$, and $\mathrm{Na}^{+}$, are in the M2 structural position in distorted polyhedron with coordination from 6 to 8 . The following cations, $\mathrm{Al}^{3+}, \mathrm{Fe}^{3+}, \mathrm{Fe}^{2+}, \mathrm{Ti}^{3+}, \mathrm{Cr}^{3+}, \mathrm{V}^{3+}$, etc., are in the M1 octahedral position. Ions $\mathrm{Si}^{4+}$ and $\mathrm{Al}^{3+}$ are in tetrahedral position forming single chain. Natural diopside commonly contains various amounts of the 
ions $\mathrm{Fe}^{2+}$ and forms complete solid solution with hedenbergite $\left(\mathrm{CaFe}^{2+} \mathrm{Si}_{2} \mathrm{O}_{6}\right)$ due to similar charge and ionic size of $\mathrm{Mg}^{2+}$ and $\mathrm{Fe}^{2+}$ [12].

The crystal structure of a synthetic $\mathrm{CaFe}^{3+} \mathrm{SiAlO}_{6}$ pyroxene was determined by single crystal $\mathrm{X}$-ray diffraction [13]. One of the most interesting aspects of the synthetic $\mathrm{CaFe}^{3+} \mathrm{SiAlO}_{6}$ structure is the fact that $\mathrm{Fe}^{3+}$ ions are not concentrated solely at the octahedral M1 site, but are partitioned between the M1 site and the tetrahedral T site.

We suggest that the incorporation of iron into diopside structure in different structural positions can lead to synthesis of ceramic pigments.

Thus, the purpose of the study is to synthesize ceramic pigments based on stoichiometric diopside in the system $\mathrm{CaO}-\mathrm{Fe}_{2} \mathrm{O}_{3}-\mathrm{MgO}-\mathrm{SiO}_{2}$ with various content of iron oxide additive and study the change in mineralogical composition, structural features and changes in color parameters of the resulting pigments.

\section{Experimental}

For the preparation of the diopside ceramic pigments in the system $\mathrm{CaO}-\mathrm{Fe}_{2} \mathrm{O}_{3}-\mathrm{MgO}-\mathrm{SiO}_{2}$, the starting compositions were determined from the basic mineral diopside following the expression $\mathrm{CaO} \cdot \mathrm{xFe}_{2} \mathrm{O}_{3} \cdot(1-\mathrm{x}) \mathrm{MgO} \cdot 2 \mathrm{SiO}_{2}$, where $\mathrm{x}=0.1,0.2,0.3$, 0.4 and 0.5 mole. Ceramic pigments were synthesized via solid-state high temperature sintering.

Starting materials used for the synthesis were $\mathrm{CaCO}_{3}, \mathrm{Fe}_{2} \mathrm{O}_{3}, \mathrm{MgO}$ and $\mathrm{SiO}_{2} \cdot \mathrm{nH}_{2} \mathrm{O}$ with particle size in the range of $2-7 \mu \mathrm{m}$, which is much more reactive than conventionally used quartz sand as a source of $\mathrm{SiO}_{2}$. Calculated quantities of materials for $100 \mathrm{~g}$ batch were weighed with a precision, then mixed and dry homogenized in a planetary mill Pulverizete-6 (Fritch). Synthesis was carried out in a laboratory muffle furnace in porcelain crucibles with at the heating rate of $300-400^{\circ} \mathrm{C} / \mathrm{h}$ in air with isothermal retention during 2 hour at the final temperature. The resulting powder mixtures were sintered at 1000,1100 and $1200^{\circ} \mathrm{C}$ in order to obtain Fe-doped diopside.

The resulting ceramic pigments were examined by powder X-ray diffraction (XRD) analysis, infrared spectroscopy (FT-IR), electron paramagnetic resonance (EPR), Mössbauer spectroscopy. The color was determined by spectrophotometry technique.

The phase composition of the synthesized ceramic pigments was determined using an X-ray diffractometer Empyrean, Malvern Panalytical operating at $40 \mathrm{kV}$ and $30 \mathrm{~mA}$ with $\mathrm{CuK}_{\alpha}$ radiation.

FT-IR spectra were collected using a Tensor 37 spectrometer (Bruker) with $4 \mathrm{~cm}^{-1}$ resolution after averaging 128 scans on standard $\mathrm{KBr}$ pallets in the spectral region of $400-4000 \mathrm{~cm}^{-1}$ at room temperature.

The Bruker EMXplus Spectrometer System (9.4 GHz - X-band region) was used to perform EPR analysis.

Mössbauer spectra were recorded by a Wissel (Wissenschaftliche Elektronik GmbH, Germany) electromechanical spectrometer working in a constant acceleration mode at room temperature (RT). A ${ }^{57} \mathrm{Co} / \mathrm{Rh}$ source (activity of $\cong 20 \mathrm{mCi}$ ) and an $\alpha-\mathrm{Fe}$ standard were used.

The colors of the pigments were determined by Lovibont Tintometer RT 100 Color and presented in the CIELab color space.

\section{Results and discussion}

$X$-ray diffraction (XRD) analysis

The powder XRD data revealed that the ceramic pigments synthesized at different temperature and $\mathrm{Fe}_{2} \mathrm{O}_{3}$ content vary in their phase composition

Table 1

Results of powder XRD phase composition

\begin{tabular}{|c|c|c|c|c|c|}
\hline $\begin{array}{c}\mathrm{Fe}_{2} \mathrm{O}_{3} \text { content } \\
\text { mole }\end{array}$ & $\mathrm{T},{ }^{0} \mathrm{C}$ & Phases & $\begin{array}{c}\mathrm{Fe}_{2} \mathrm{O}_{3} \text { content, } \\
\text { mole }\end{array}$ & $\mathrm{T},{ }^{0} \mathrm{C}$ & Phases \\
\hline \multirow{3}{*}{0.1} & 1000 & $\begin{array}{l}\text { wollastonite, periclase, diopside, } \\
\text { akermanite }\end{array}$ & \multirow{3}{*}{0.3} & 1000 & $\begin{array}{l}\text { wollastonite, diopside, } \\
\text { akermanite, periclase }\end{array}$ \\
\hline & 1100 & $\begin{array}{l}\text { wollastonite, akermanite, } \\
\text { diopside }\end{array}$ & & 1100 & $\begin{array}{l}\text { wollastonite, diopside, } \\
\text { akermanite, cristobalite, periclase }\end{array}$ \\
\hline & 1200 & $\begin{array}{l}\text { diopside, cristobalite, } \\
\text { wollastonite, akermanite }\end{array}$ & & 1200 & $\begin{array}{l}\text { Fe-diopside, cristobalite, } \\
\text { wollastonite }\end{array}$ \\
\hline \multirow{3}{*}{0.2} & 1000 & $\begin{array}{l}\text { wollastonit, diopside, periclase, } \\
\text { akermanite }\end{array}$ & \multirow{3}{*}{0.4} & 1000 & $\begin{array}{l}\text { wollastonite, hematite, periclase, } \\
\text { diopside, akermanite }\end{array}$ \\
\hline & 1100 & $\begin{array}{l}\text { diopside, wollastonite, } \\
\text { akermanite, cristobalite, } \\
\text { periclase }\end{array}$ & & 1100 & wollastonite, hematite, diopside \\
\hline & 1200 & $\begin{array}{l}\text { Fe-diopside, cristobalite, } \\
\text { wollastonite }\end{array}$ & & 1200 & Fe-diopside, cristobalite, hematite \\
\hline
\end{tabular}




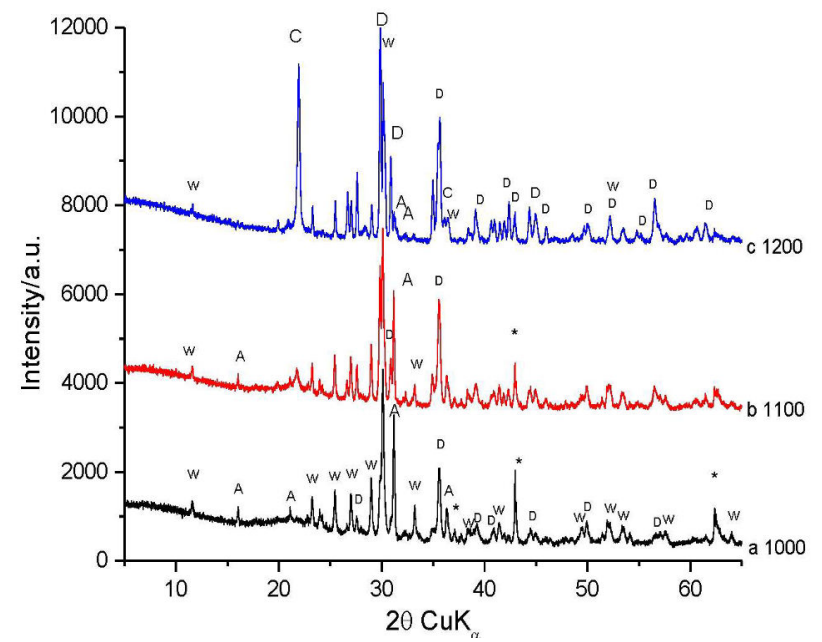

a
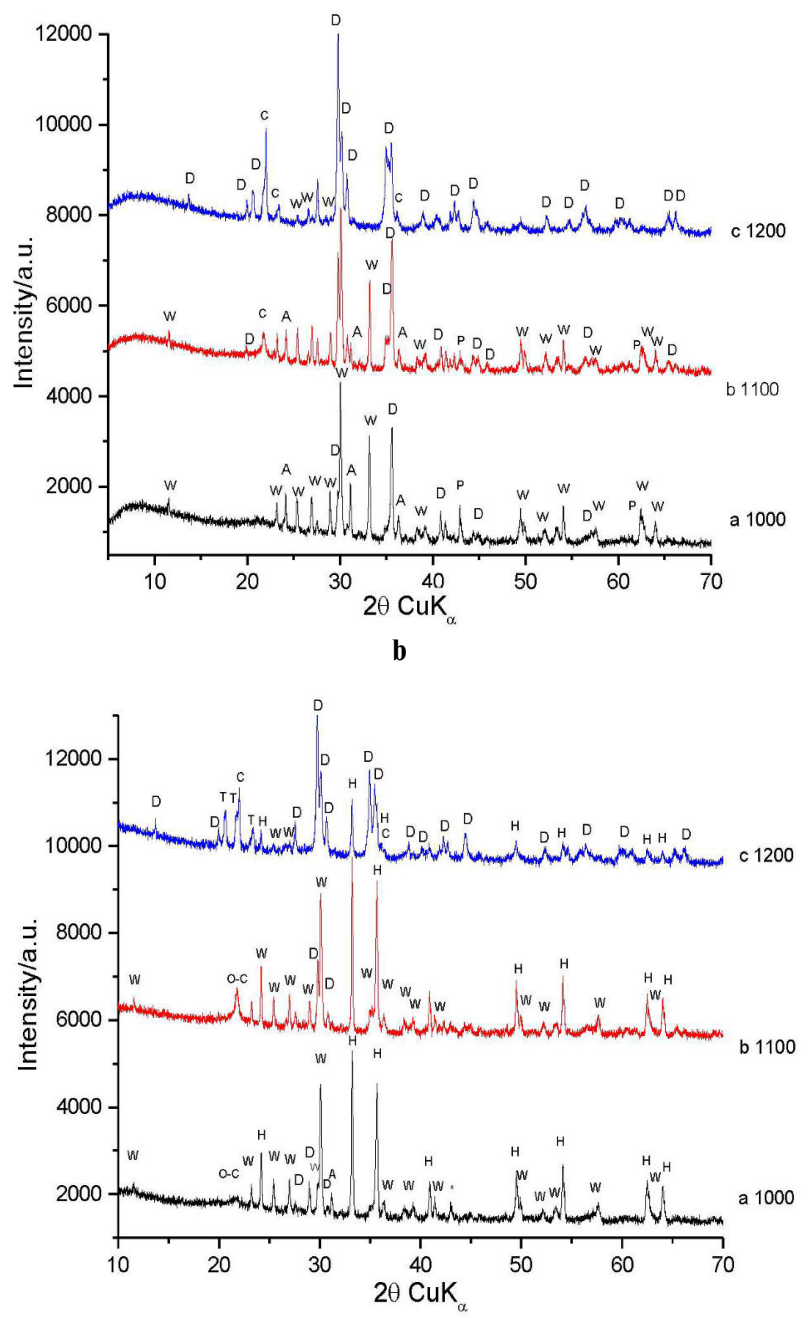

c

Fig. 1. Powder XRD patterns of samples

$\mathrm{CaO} \cdot 0.1 \mathrm{Fe}_{2} \mathrm{O}_{3} \cdot 0.9 \mathrm{MgO} \cdot 2 \mathrm{SiO}_{2}$ (a), $\mathrm{CaO} \cdot 0.3 \mathrm{Fe}_{2} \mathrm{O}_{3} \cdot 0.7 \mathrm{MgO} \cdot 2 \mathrm{SiO}_{2}$

(b) and $\mathrm{CaO} \cdot 0.5 \mathrm{Fe}_{2} \mathrm{O}_{3} \cdot 0.5 \mathrm{MgO} \cdot 2 \mathrm{SiO}_{2}$ (c) sintered at 1000,1100 and $1200^{\circ} \mathrm{C}: \mathrm{D}-$ diopside, $\mathrm{W}-$ wollastonite,

$\mathrm{C}-\beta$-cristobalite, $\mathrm{A}-$ akermanite, $\mathrm{P}-$ periclase, $\mathrm{H}-$ hematite
(Table 1). X-ray diffraction patterns of the synthesized ceramic pigments are shown in Fig. 1.

Powder XRD patterns of the synthesized ceramic pigments $\mathrm{CaO} \cdot \mathrm{xFe}_{2} \mathrm{O}_{3} \cdot(1-\mathrm{x}) \mathrm{MgO} \cdot 2 \mathrm{SiO}_{2}$ at different temperatures $\left(1000^{\circ} \mathrm{C} ; 1100^{\circ} \mathrm{C} ; 1200^{\circ} \mathrm{C}\right)$ and initial iron content $x=0.1,0.2,0.3,0.4$, and 0.5 mole revealed variations in phase composition depending on the initial iron oxide concentration and synthesis temperature.

At low temperature $\left(1000^{\circ} \mathrm{C}\right)$, the predominate phase is wollastonite $\left(\mathrm{CaSiO}_{3}\right)$. Diopside $\left(\mathrm{CaMgSi}_{2} \mathrm{O}_{6}\right)$ and akermanite $\left(\mathrm{Ca}_{2} \mathrm{MgSi}_{2} \mathrm{O}_{7}\right)$ are also formed in smaller quantities. Unreacted magnesium oxide remains in the form of periclase. At low content of iron oxide in the initial batch ( 0.1 mole to 0.3 mole), no separate iron oxide phases are detected, which means that iron oxide was successfully doped into the structure of the formed mineral phases. At higher content of iron oxide ( $\geq 0.4$ mole), the excess of iron oxide leads to the formation of hematite $\left(\alpha-\mathrm{Fe}_{2} \mathrm{O}_{3}\right)$.

With increasing the temperature to $1100^{\circ} \mathrm{C}$, the amount of diopside increases and separate $\mathrm{SiO}_{2}$ appears as $\beta$-cristobalite. Diopside and Fe-diopside predominates in samples sintered at $1200^{\circ} \mathrm{C}$ at iron concentrations above 0.1 mole. At the temperature of $1200^{\circ} \mathrm{C}$, hematite is detected only at highest iron oxide content $(0.5$ mole $)$. Probably at the concentrations of up to 0.3 mole, the whole amount of iron oxide is incorporated into diopside structure.

FT-IR analysis

FT-IR spectra of the iron-doped diopside ceramic pigments are shown in Fig. 2. Infrared peaks of diopside and other possible silicate phases peaks are summarized in Table 2.

Table 2

Infrared peaks of diopside and other possible silicate phases and their assignment

\begin{tabular}{c|c|c|c}
\hline $\begin{array}{c}\text { Diopside } \\
\mathrm{CaMgSi}_{2} \mathrm{O}_{6}\end{array}$ & $\begin{array}{c}\text { Wollastonite } \\
\mathrm{CaSiO}_{3}\end{array}$ & $\begin{array}{c}\text { Akermanite } \\
\mathrm{Ca}_{2} \mathrm{MgSi}_{2} \mathrm{O}_{7}\end{array}$ & $\begin{array}{c}\text { Type of } \\
\text { vibration }\end{array}$ \\
\hline 1072 & 1090 & 1024 & $\mathrm{Si}-\mathrm{O}-\mathrm{Si}$ \\
960 & 1060 & 974 & stretching \\
920 & 1040 & 935 & $\mathrm{Si-O}$ \\
860 & $\begin{array}{c}1020 \\
\text { stretching }\end{array}$ \\
& 967 & 852 & \\
\hline & 679 & 675 & $\begin{array}{c}\mathrm{Si}-\mathrm{O}-\mathrm{Si} \\
\text { stretching }\end{array}$ \\
\hline 630 & 645 & 656 & $\mathrm{Si}-\mathrm{O}-\mathrm{Si}$ bend \\
\hline & & 586 & $\mathrm{Ca}-\mathrm{O}$ \\
\hline 515 & 470 & 486 & $\begin{array}{c}\mathrm{O}-\mathrm{Si}-\mathrm{O} \\
\text { bend } \\
\text { O-Mg-O }\end{array}$ \\
\hline 510 & 450 & &
\end{tabular}




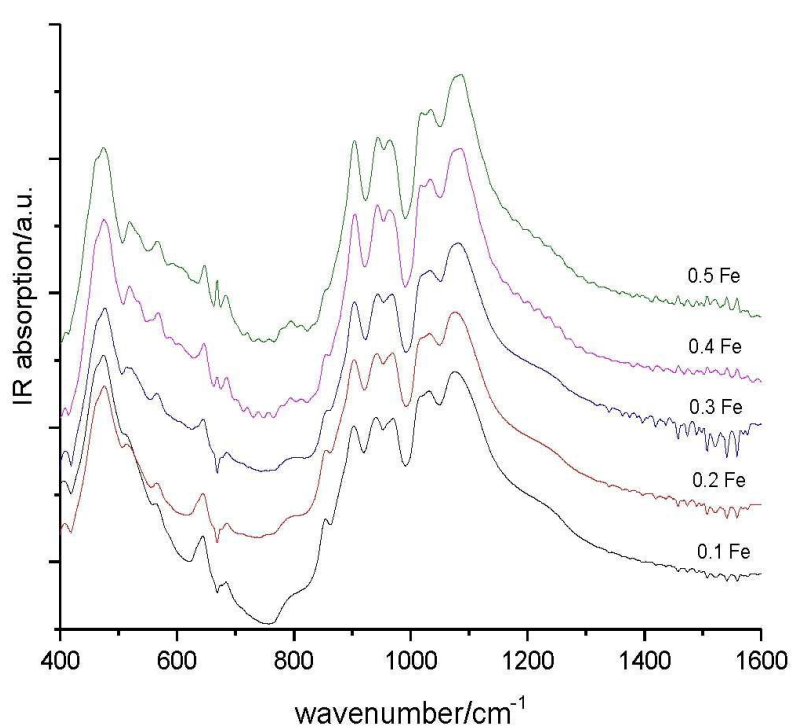

a

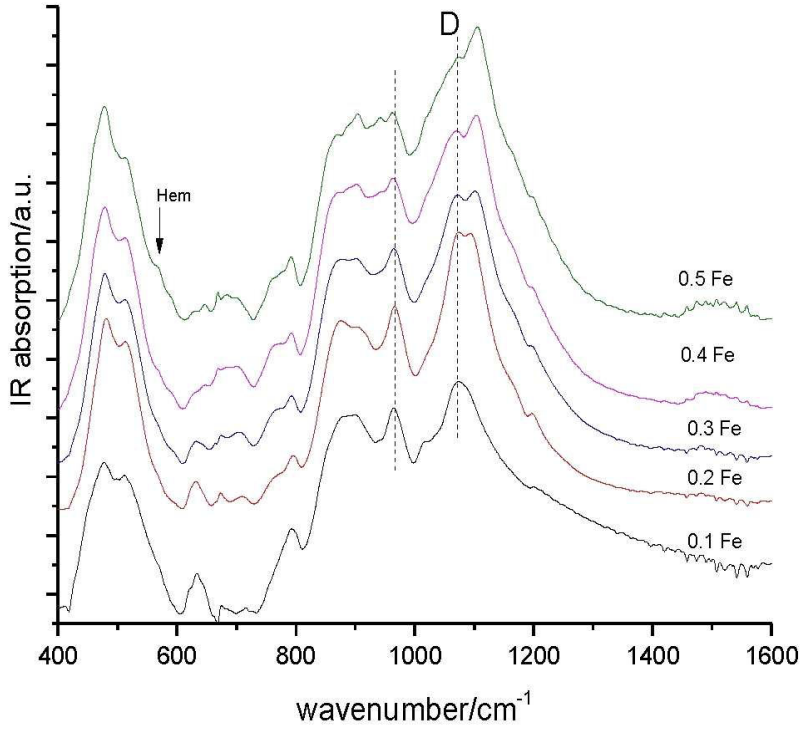

b

Fig. 2. FT-IR spectra of the iron-doped diopside ceramic pigments with different content of $\mathrm{Fe}_{2} \mathrm{O}_{3}$ synthesized at $1000^{\circ} \mathrm{C}$ (a) and $1200^{\circ} \mathrm{C}($ b)

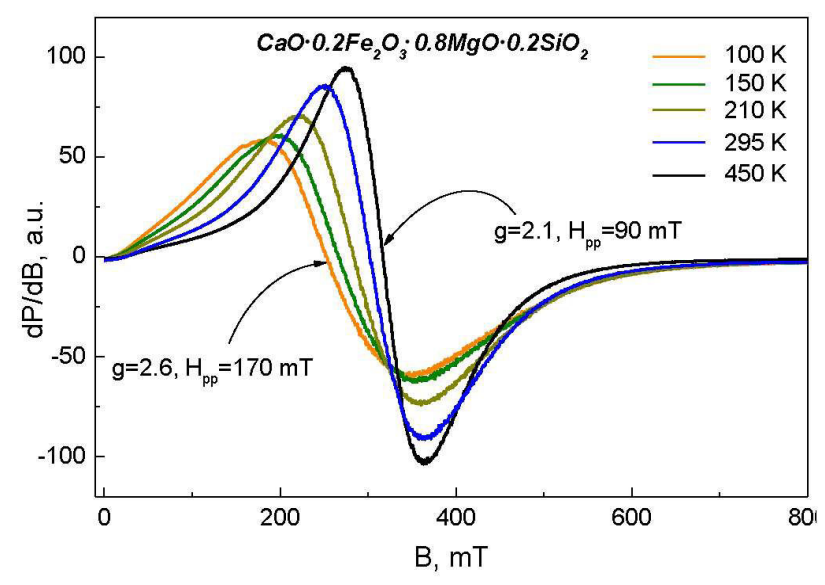

a

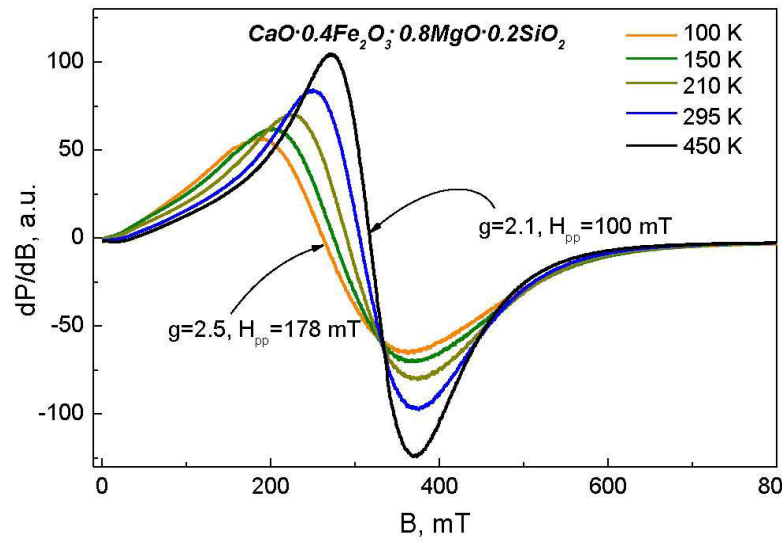

b

Fig. 3. EPR spectra of the following samples: $\mathrm{CaO} \cdot 0.2 \mathrm{Fe}_{2} \mathrm{O}_{3} \cdot 0.8 \mathrm{MgO} \cdot 2 \mathrm{SiO}_{2}$ (a) and $\mathrm{CaO} \cdot 0.4 \mathrm{Fe}_{2} \mathrm{O}_{3} \cdot 0.6 \mathrm{MgO} \cdot 2 \mathrm{SiO}_{2}$ (b) in temperature range of $100-450 \mathrm{~K}$

Intense peaks at 1072, near 960 and $860 \mathrm{~cm}^{-1}$ are due to $\mathrm{Si}-\mathrm{O}$ stretching in diopside. A peak at $515 \mathrm{~cm}^{-1}$ is characteristic for $\mathrm{O}-\mathrm{Mg}-\mathrm{O}$ bending vibrations in diopside. Similar peaks in akermanite should be at 1024, 974, 935 and $852 \mathrm{~cm}^{-1}$ due to $\mathrm{Si}-\mathrm{O}-\mathrm{Si}$ and $\mathrm{Si}-\mathrm{O}$ stretching modes, while these peaks should be at 1060, 1000 and $900 \mathrm{~cm}^{-1}$ in wollastonite [14]. Peaks of these phases overlap and only the intensity ratio could be an indication for the composition change. The increase of the peak near $1200 \mathrm{~cm}^{-1}$ confirms an increase in the free $\mathrm{SiO}_{2}$ content in the ceramic pigments obtained at $1200^{\circ} \mathrm{C}$.

Electron paramagnetic resonance

EPR spectra of samples with the following composition $\mathrm{CaO} \cdot \mathrm{xFe}_{2} \mathrm{O}_{3} \cdot(1-\mathrm{x}) \mathrm{MgO} \cdot 2 \mathrm{SiO}_{2}(\mathrm{x}=0.2$ and 0.4 mole) are presented as the first derivative of absorption curve $(\mathrm{dP} / \mathrm{dB})$ versus magnetic field $(\mathrm{B}, \mathrm{mT})$ in Fig. 3.

The shape of considered signals and temperature dependence of their EPR parameters are an indication of the presence of effective exchange interactions occurring between $\mathrm{Fe}^{3+}$ ions. The recorded signals can be associated with the presence of a phase of $\mathrm{Fe}_{2} \mathrm{O}_{3}$ in the superparamagnetic state, i.e. with the existence of nanosized particles representing magnetic domains. The observed linear dependence (Fig. 4) is a proof that the nanodomains in the powder sample are homogeneous in size and composition. 


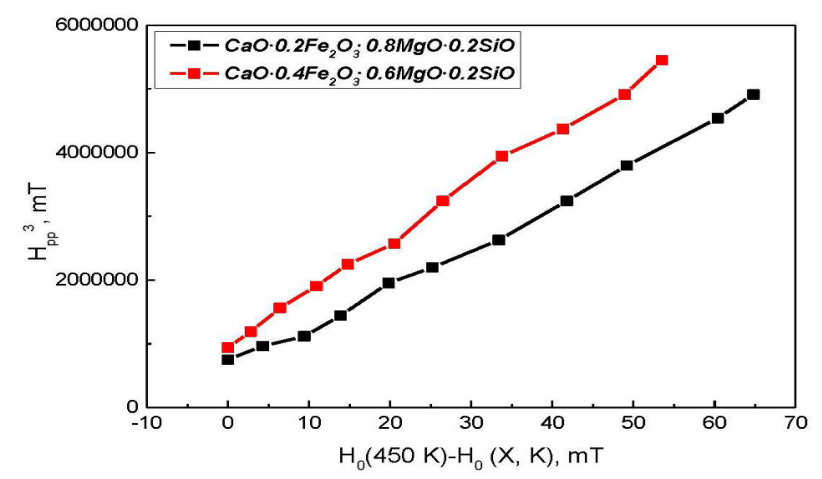

Fig. 4. Dependence of the third degree of peak to peak line width $\left(\Delta \mathrm{H}_{\mathrm{pp}}{ }^{3}\right)$ on signal shift to weaker magnetic field with

lowering the registration temperature for the samples $\mathrm{xFe}_{2} \mathrm{O}_{3} \cdot(1-\mathrm{x}) \cdot \mathrm{MgO} \cdot 2 \mathrm{SiO}_{2}(\mathrm{x}=0.2$ and 0.4 mole $): \mathrm{B}_{0}-$ center field at $450 \mathrm{~K}, \mathrm{~B}_{0}(\mathrm{~K})$ - center field at given temperature in the temperature range of $100-450 \mathrm{~K}$

\section{Mössbauer spectroscopy}

Mössbauer spectroscopy was used to identify the structural position of iron ions in the samples sintered at $1200^{\circ} \mathrm{C}$ with the $\mathrm{Fe}_{2} \mathrm{O}_{3}$ content of 0.2 mole and 0.4 mole. As can be seen from XRD phase composition (Table 1), the predominant crystalline

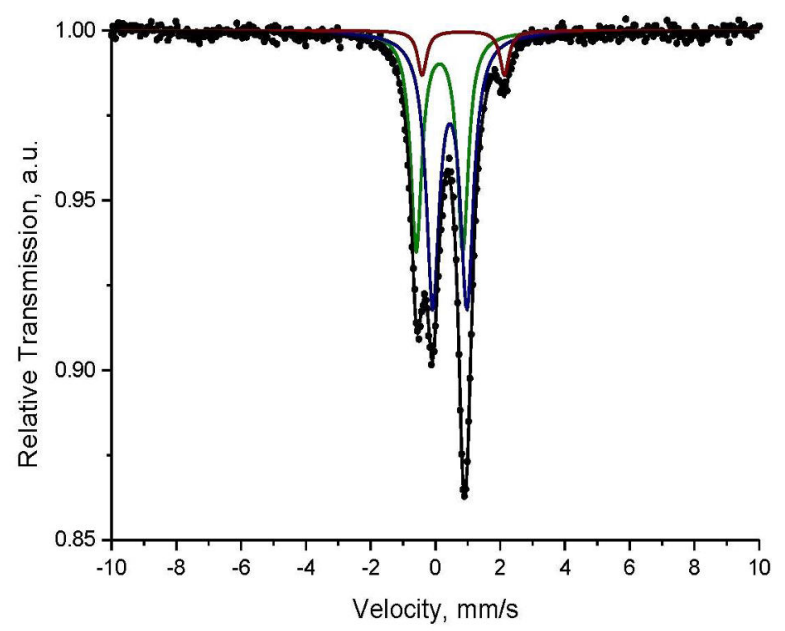

a phase is Fe-diopside. The other accompanying phase is hematite, which is formed by an excess of iron above 0.3 mole $\mathrm{Fe}_{2} \mathrm{O}_{3}$ in the initial batch.

The experimental Mössbauer spectra of the samples with initial $\mathrm{Fe}_{2} \mathrm{O}_{3}$ content of 0.2 mole and 0.4 mole sintered at $1200^{\circ} \mathrm{C}$ are shown in Fig. 5 .

Figure 5 shows a combination of doublets for the sample with 0.2 mole $\mathrm{Fe}_{2} \mathrm{O}_{3}$ and doublets and sextet for the sample with 0.4 mole $\mathrm{Fe}_{2} \mathrm{O}_{3}$. The mathematical processing was performed according to the type of spectra: a model with three doublets was used for sample 16c, and three doublets and one sextet was used for sample 18c. The results of the spectrum processing are given in Table 3 .

The obtained ultrafine parameters of the doublets can be explained according to ref. [15] as follows:

- Db1 $\mathrm{Fe}^{3+}$ in tetrahedral positions $\left(\mathrm{Si}^{4+}\right)$ in the ferri-diopside phase;

- Db2 $\mathrm{Fe}^{3+}$ in octahedral positions (M1) in the ferri-diopside phase;

- Db3 $\mathrm{Fe}^{2+}$ at M1 and / or M2 positions in the ferri-diopside phase;

- The sextet component in sample 18c has typical parameters for hematite.

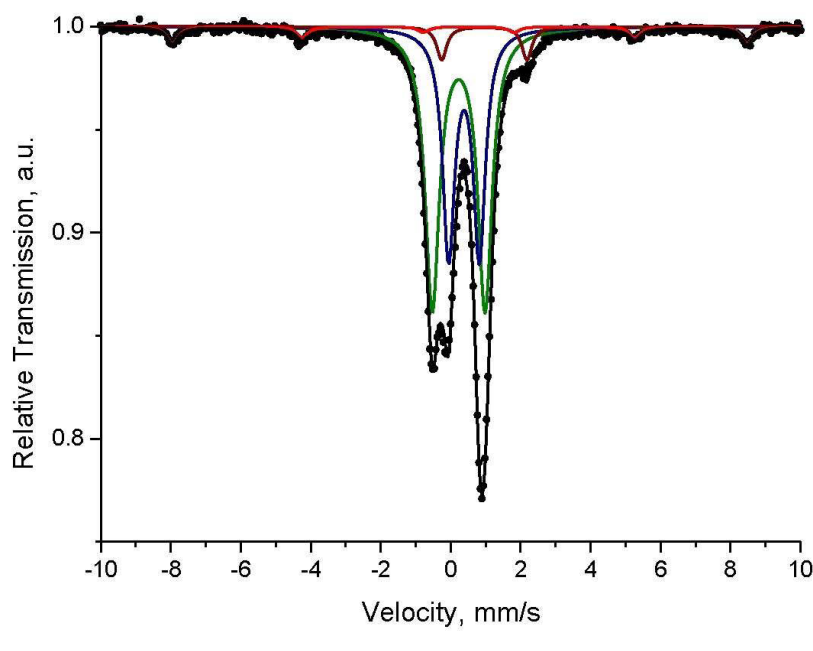

b

Fig. 5. Mössbauer spectra of the samples with the initial Fe content of $0.2 \mathrm{Fe}_{2} \mathrm{O}_{3}$ (a) and $0.4 \mathrm{Fe}_{2} \mathrm{O}_{3}$

Table 3

Mössbauer parameters of the studied samples

\begin{tabular}{|c|c|c|c|c|c|c|}
\hline Sample & Components & $\delta, \mathrm{mm} / \mathrm{s}$ & $\Delta(2 \varepsilon), \mathrm{mm} / \mathrm{s}$ & $\mathrm{B}_{\mathrm{hf}}, \mathrm{T}$ & $\Gamma_{\text {exp }}, \mathrm{mm} / \mathrm{s}$ & $\mathrm{G}, \%$ \\
\hline $16 \mathrm{c}$, & $\mathrm{Db} 1-\mathrm{Fe}^{3+}{ }_{\text {tetra }}$ & 0.13 & 1.44 & - & 0.41 & 39 \\
\hline $\mathrm{CaO} \cdot 0.2 \mathrm{Fe}_{2} \mathrm{O}_{3} \cdot 0.8 \mathrm{MgO} \cdot 2 \mathrm{SiO}_{2}$ & $\mathrm{Db} 2-\mathrm{Fe}^{3+}{ }_{\text {octa }}, \mathrm{M} 1$ & 0.45 & 0.06 & - & 0.49 & 55 \\
\hline $1914-211$ & $\mathrm{Db} 3-\mathrm{Fe}^{2+}$ & 0.86 & 2.54 & - & 0.33 & 6 \\
\hline $18 \mathrm{c}$ & $\mathrm{Db} 1-\mathrm{Fe}^{3+}$ tetra & 0.23 & 1.51 & - & 0.49 & 54 \\
\hline $\mathrm{CaO} \cdot 0.4 \mathrm{Fe}_{2} \mathrm{O}_{3} \cdot 0.6 \mathrm{MgO} \cdot 2 \mathrm{SiO}_{2}$ & $\mathrm{Db} 2-\mathrm{Fe}^{3+}{ }_{\text {octa }}, \mathrm{M} 1$ & 0.31 & 0.88 & - & 0.42 & 37 \\
\hline $1915-211$ & $\mathrm{Db} 3-\mathrm{Fe}^{2+}$ & 0.96 & 2.44 & - & 0.34 & 4 \\
\hline & $\mathrm{Sx}-\mathrm{Fe}^{3+}{ }_{\text {octa }}, \alpha-\mathrm{Fe}_{2} \mathrm{O}_{3}$ & 0.39 & -0.25 & 50.9 & 0.40 & 5 \\
\hline
\end{tabular}


Results obtained from the measurement of the color coordinates

\begin{tabular}{c|c|c|c|c}
\hline \multicolumn{1}{c|}{ Composition } & Color & $\mathrm{L}^{*}$ & $\mathrm{a}^{*}$ & $\mathrm{~b}^{*}$ \\
\hline $\mathrm{CaO} \cdot 0.2 \mathrm{Fe}_{2} \mathrm{O}_{3} \cdot 0.8 \mathrm{MgO} \cdot 2 \mathrm{SiO}_{2}\left(1000^{\circ} \mathrm{C}\right)$ & & 50.8 & 22.5 & 27.3 \\
\hline $\mathrm{CaO} \cdot 0.2 \mathrm{Fe}_{2} \mathrm{O}_{3} \cdot 0.8 \mathrm{MgO} \cdot 2 \mathrm{SiO}_{2}\left(1100^{\circ} \mathrm{C}\right)$ & & 59.8 & 19.9 & 29.9 \\
\hline $\mathrm{CaO} \cdot 0.2 \mathrm{Fe}_{2} \mathrm{O}_{3} \cdot 0.8 \mathrm{MgO} \cdot 2 \mathrm{SiO}_{2}\left(1200^{\circ} \mathrm{C}\right)$ & & 64.9 & 6.0 & 31.1 \\
\hline $\mathrm{CaO} \cdot 0.3 \mathrm{Fe}_{2} \mathrm{O}_{3} \cdot 0.7 \mathrm{MgO} \cdot 2 \mathrm{SiO}_{2}\left(1000^{\circ} \mathrm{C}\right)$ & & 44.5 & 24.1 & 25.8 \\
\hline $\mathrm{CaO} \cdot 0.3 \mathrm{Fe}_{2} \mathrm{O}_{3} \cdot 0.7 \mathrm{MgO} \cdot 2 \mathrm{SiO}_{2}\left(1100^{\circ} \mathrm{C}\right)$ & & 49.6 & 23.7 & 26.3 \\
\hline $\mathrm{CaO} \cdot 0.3 \mathrm{Fe}_{2} \mathrm{O}_{3} \cdot 0.7 \mathrm{MgO} \cdot 2 \mathrm{SiO}_{2}\left(1200^{\circ} \mathrm{C}\right)$ & & 62.1 & 6.1 & 32.6 \\
\hline $\mathrm{CaO} \cdot 0.4 \mathrm{Fe}_{2} \mathrm{O}_{3} \cdot 0.6 \mathrm{MgO} \cdot 2 \mathrm{SiO}_{2}\left(1000^{\circ} \mathrm{C}\right)$ & & 41.5 & 25.7 & 23.6 \\
\hline $\mathrm{CaO} \cdot 0.4 \mathrm{Fe}_{2} \mathrm{O}_{3} \cdot 0.6 \mathrm{MgO} \cdot 2 \mathrm{SiO}_{2}\left(1100^{\circ} \mathrm{C}\right)$ & & 43.9 & 24.2 & 24.6 \\
\hline $\mathrm{CaO} \cdot 0.4 \mathrm{Fe}_{2} \mathrm{O}_{3} \cdot 0.6 \mathrm{MgO} \cdot 2 \mathrm{SiO}_{2}\left(1200^{\circ} \mathrm{C}\right)$ & & 58.6 & 7.4 & 31.9 \\
\hline
\end{tabular}

\section{Color measurement}

Color is one of the most important indicators of the pigment quality. The expected color derived from $\mathrm{Fe}^{3+}$ ions substitution in the octahedral position in diopside is brown. The colors of the resulting ceramic pigments were defined according to universal CIELab system. In the CIELab system, the color coordinates are as follows:

$\mathrm{L}^{*}$ (brightness), from absolute white $\mathrm{L}^{*}=100$ to absolute black $\mathrm{L}^{*}=0$,

$\mathrm{a}^{*}-$ green color $(-) /$ red color $(+)$,

$\mathrm{b}^{*}-$ blue color $(-)$ /yellow color $(+)$.

Table 4 shows the results of measuring the color indicators of the developed diopside pigments.

The results of the measurement of the color coordinates show that as the firing temperature increases from $1000^{\circ} \mathrm{C}$ to $1200^{\circ} \mathrm{C}$, the color of the pigments changes from brown to beige. As the firing temperature increases, there is a tendency for the brightness $\mathrm{L}^{*}$ to increase from $41.5-50.8$ to $58.6-$ $64.9 \%$, while the coordinates $\mathrm{a}^{*}$ and $\mathrm{b}^{*}$ decrease. The amount of red color $\left(a^{*}\right)$ is greatest in the ceramic pigments sintered at lower temperature $\left(1000^{\circ} \mathrm{C}\right.$ and $1100^{\circ} \mathrm{C}$ ), as it is seen from Table 4 . The value of the color coordinate $\mathrm{a}^{*}$ in this case is in the range from
+19.9 to +25.7 . This can be explained by a significant increase in the $\mathrm{SiO}_{2}$ phase content in the ceramic pigments obtained at $1200^{\circ} \mathrm{C}$ relative to the amount of Fe-diopside.

\section{Conclusions}

The brown and beige ceramic pigments were synthesized on the basis of stoichiometric diopside by the method of solid phase sintering. It was found that polyphase ceramic pigments are formed and the predominant phase is Fe-diopside. It was determined from the Mössbauer spectra that iron ions occupy different structural positions in the obtained $\mathrm{Fe}$-diopside. It was also found that the color of the ceramic pigments depends on the quantitative ratio between the mineral phases obtained. At initial $\mathrm{Fe}_{2} \mathrm{O}_{3}$ content above 0.3 mole, the hematite is separated in the resulting ceramic pigments. The amount of free crystalline $\mathrm{SiO}_{2}$ increases after firing at $1200^{\circ} \mathrm{C}$, which reduces the intensity of the pigment color.

\section{Acknowledgements}

The financial support of this work by the Bulgarian Ministry of Education and Science, National Research Fund under the contract number KP-06-H47/10-2020 is gratefully acknowledged. 


\section{REFERENCES}

1. Maslennikova G.N., Pisch I.V. Keramicheskie pigmenty. - M.: Stroymaterialy, $-2009 .-224$ p.

2. Koroleva (Chekhomova) L.F. Synthesis of spinel-based ceramic pigments from hydroxycarbonates // Glass Ceram. 2004. - Vol.61. - P.299-302.

3. Pogrebenkov V.M., Sedel'nikova M.B. Ceramic pigments based on natural minerals // Glass Ceram. - 2002. - Vol.59. P.396-399.

4. Zaichuk A.V., Belyi Ya.I. Brown ceramic pigments based on open-hearth slag // Russ. J. Appl. Chem. - 2012. - Vol.85. P.1531-1535.

5. Doynov M., Dimitrov Ts., Kozhukharov S. Alternative technological approach for synthesis of ceramic pigments by waste materials recycling // Bol. Soc. Esp. Ceram. V. - 2016. - Vol.55. - No. 2. - P.63-70.

6. Zaichuk A.V., Amelina A.A. Blue-green ceramic pigments in the system $\mathrm{CaO}-\mathrm{MgO}-\mathrm{Al}_{2} \mathrm{O}_{3}-\mathrm{SiO}_{2}-\mathrm{CoO}-\mathrm{Cr}_{2} \mathrm{O}_{3}$ based on granulated blast-furnace slag // Voprosy Khimii i Khimicheskoi Tekhnologii. - 2018. - No. 6. - P.120-124.

7. Blue cobalt doped-hibonite pigments prepared from industrial sludges: formulation and characterization / Leite A., Costa G., Hajjaji W., Ribeiro M.J., Seabra M.P., Labrincha J.A. // Dyes Pigm. - 2009. - Vol.81. - P.211-217.

8. Synthesis of Cr-doped celsian green pigments and their application / Chung H.S., Kim Y.J., Choi S.N., Lee B.H. // J. Korean. Ceram. Soc. - 2010. - Vol.47. - No. 5. - P.450-456.

9. Dimitrov T., Markovska I., Stancheva M. Zircon ceramic pigments with different d-chromophore elements for the use in glazes for wall tiles // Interceram. - 2010. - Vol.59. - No. 6. P.364-366.

10. Synthesis and study of low-temperature ferrum-willemite ceramic pigments / Dimitrov Ts.I., Ibreva Ts.H., Zaichuk A.V., Markovska I.G., Amelina A.A., Karasik E.V. // Voprosy Khimii i Khimicheskoi Tekhnologii. - 2019. - No. 6. - P.69-73.

11. Colour of $\mathrm{Ca}\left(\mathrm{Co}_{x} \mathrm{Mg}_{1-\mathrm{x}}\right) \mathrm{Si}_{2} \mathrm{O}_{6}$ pyroxenes and their technological behaviour as ceramic colorants / Gori C., Mantovani L., Tribaudino M., Zanelli C., Dondi M. // Ceram. Int. - 2018. - Vol.44. - P.12745-12753.

12. Downs R.T. Topology of the pyroxenes as a function of temperature, pressure, and composition as determined from the procrystal electron density // Am. Mineral. - 2003. - Vol.88. No. 4. - P.556-566.

13. Ghose S., Okamura F.P., Ohashi H. The crystal structure of $\mathrm{CaFe}^{3+} \mathrm{SiAlO}_{6}$ and the crystal chemistry of $\mathrm{Fe}^{3+}-\mathrm{Al}^{3+}$ substitution in calcium Tschermak's pyroxene // Contrib. Mineral. Petrol. - 1986. - Vol.92. - P.530-535.

14. Chukanov N.V. Infrared spectra of mineral species. Dordrecht: Springer, 2014. - 1726 p.

15. Hafner S., Huckenholz $H$. Mossbauer spectrum of synthetic ferri-diopside // Nat. Phys. Sci. - 1971. - Vol.233. P.9-11.

Received 16.09.2021

\section{СИНТЕЗ ТА ДОСЛІДЖЕННЯ ФЕРУМДІОПСИДНИХ КЕРАМІЧНИХ ПІГМЕНТІВ}

\section{Ц.І. Дімітров, Р.Х. Тіторенкова, О.В. Зайчук, Я.К. Цвєтанова}

У статті досліджено мінералогічний склад, структурні особливості та зміну колірних параметрів залізовмісних пігментів діопсиду. Джерелом $\mathrm{SiO}_{2}$ у таких пігментах був $\mathrm{SiO}_{2} \cdot \mathrm{nH}_{2} \mathrm{O}$ із розміром частинок у діапазоні 2-7 мкм, що набагато активніші, ніж звичайний кварцовий пісок. Серія керамічних пігментів на основі стехіометричного діопсиду в системі $\mathrm{CaO}-\mathrm{Fe}_{2} \mathrm{O}_{3}-\mathrm{MgO}-\mathrm{SiO}_{2}$ була синтезована твердотільним високотемпературним спіканням при 1000, 1100 та $1200^{\circ} \mathrm{C}$. Одержані керамічні пігменти досліджували методом порошкової рентгенівської дифракції, інфрачервоної спектроскопії, електронної мікроскопії, електронного парамагнітного резонансу, месбауєрівської спектроскопії. Кольорові характеристики вимірювали спектрофотометрично. Встановлено, що в умовах синтезу були одержані багатофазні керамічні пігменти, які містять у різній пропорції діопсид, воластоніт, кристобаліт, акерманіт і периклаз. Синтезовані керамічні пігменти мають коричневий і бежевий колір залежно від вмісту добавки $\mathrm{Fe}_{2} \mathrm{O}_{3}$, температури випалу та фазового складу. Розроблені пігменти використовують для забарвлення керамічної глазурі.

Ключові слова: керамічні пігменти, діопсид, мінеральний склад, колориметричні показники, синтез.

\section{SYNTHESIS AND STUDY OF FERRI-DIOPSIDE CERAMIC PIGMENTS}

\section{Ts.I. Dimitrov ${ }^{a,}{ }^{*}$, R.H. Titorenkova ${ }^{b}$, A.V. Zaichuk ${ }^{c}$, Y.K. Tzvetanova ${ }^{b}$}

a University of Ruse «Angel Kanchev», Branch Razgrad, Bulgaria

b Institute of Mineralogy and Crystallography «Acad. I. Kostov», Bulgarian Academy of Sciences, Sofia, Bulgaria

c Ukrainian State University of Chemical Technology, Dnipro, Ukraine

* e-mail: tz_dimitrow@abv.bg

The article reports the mineralogical composition, structural features and changes in color parameters of iron-containing diopside pigments. The source of $\mathrm{SiO}_{2}$ in these pigments was $\mathrm{SiO}_{2} \cdot \mathrm{nH}_{2} \mathrm{O}$ with a particle size in the range of 2-7 $\mu \mathrm{m}$, which is much more reactive than conventionally used quartz sand. A series of ceramic pigments on the basis of stoichiometric diopside in the system $\mathrm{CaO}-\mathrm{Fe}_{2} \mathrm{O}_{3}-\mathrm{MgO}-\mathrm{SiO}_{2}$ was synthesized via solidstate high temperature sintering at 1000,1100 and $1200^{\circ} \mathrm{C}$. The resulting ceramic pigments were examined by powder X-ray diffraction, infrared spectroscopy, electron microscopy, electron paramagnetic resonance and Mössbauer spectroscopy. The color characteristics were measured using spectrophotometry method. It was found that multiphase ceramic pigments were obtained under the synthesis conditions, which contain diopside, wollastonite, cristobalite, akermanite and periclase in various proportions. The synthesized ceramic pigments are brown and beige in color, depending on the content of $\mathrm{Fe}_{2} \mathrm{O}_{3}$ additive, firing temperature and phase composition. The synthesized pigments can be used for staining of ceramic glazes.

Keywords: ceramic pigments; diopside; mineral composition; colorimetric indices; synthesis. 


\section{REFERENCES}

1. Maslennikova GN, Pisch IV. Keramicheskie pigmenty [Ceramic pigments]. Moscow: Stroymaterialy Publishers; 2009. 224 p. (in Russian).

2. Koroleva (Chekhomova) LF. Synthesis of spinel-based ceramic pigments from hydroxycarbonates. Glass Ceram. 2004; 61: 299-302. doi: 10.1023/B:GLAC.0000048695.24873.a9.

3. Pogrebenkov VM, Sedel'nikova MB. Ceramic pigments based on natural minerals. Glass Ceram. 2002; 59: 396-399. doi: 10.1023/A:1022536525362.

4. Zaichuk AV, Belyi YaI. Brown ceramic pigments based on open-hearth slag. Russ J Appl Chem. 2012; 85: 1531-1535. doi: 10.1134/S1070427212100072.

5. Doynov M, Dimitrov Ts, Kozhukharov S. Alternative technological approach for synthesis of ceramic pigments by waste materials recycling. Bol Soc Esp Ceram V. 2016; 55(2): 63-70. doi: 10.1016/j.bsecv.2016.01.002.

6. Zaichuk AV, Amelina AA. Blue-green ceramic pigments in the system $\mathrm{CaO}-\mathrm{MgO}-\mathrm{Al}_{2} \mathrm{O}_{3}-\mathrm{SiO}_{2}-\mathrm{CoO}-\mathrm{Cr}_{2} \mathrm{O}_{3}$ based on granulated blast-furnace slag. Voprosy Khimii i Khimicheskoi Tekhnologii. 2018; (6): 120-124. doi: 10.32434/0321-4095-2018-121-6-120-124.

7. Leite A, Costa G, Hajjaji W, Ribeiro MJ, Seabra MP, Labrincha JA. Blue cobalt doped-hibonite pigments prepared from industrial sludges: formulation and characterization. Dyes Pigm. 2009; 81: 211-217. doi: 10.1016/j.dyepig.2008.10.008.

8. Chung HS, Kim YJ, Choi SN, Lee BH. Synthesis of $\mathrm{Cr}$-doped celsian green pigments and their application. $J$ Korean Ceram Soc. 2010; 47(5): 450-456. doi: 10.4191/kcers.2010.47.5.450.
9. Dimitrov T, Markovska I, Stancheva M. Zircon ceramic pigments with different d-chromophore elements for the use in glazes for wall tiles. Interceram. 2010; 59(6): 364-366.

10. Dimitrov TsI, Ibreva TsH, Zaichuk AV, Markovska IG, Amelina AA, Karasik EV. Synthesis and study of low-temperature ferrum-willemite ceramic pigments. Voprosy Khimii i Khimicheskoi Tekhnologii. 2019; (6): 69-73.

doi: 10.32434/0321-4095-2019-127-6-69-73.

11. Gori C, Mantovani L, Tribaudino M, Zanelli C, Dondi M Colour of $\mathrm{Ca}\left(\mathrm{Co}_{x} \mathrm{Mg}_{1-x}\right) \mathrm{Si}_{2} \mathrm{O}_{6}$ pyroxenes and their technological behaviour as ceramic colorants. Ceram Int. 2018; 44: 12745-12753. doi: 10.1016/j.ceramint.2018.04.078.

12. Downs RT. Topology of the pyroxenes as a function of temperature, pressure, and composition as determined from the procrystal electron density. Am Mineral. 2003; 88(4): 556-566. doi: 10.2138/am-2003-040.

13. Ghose S, Okamura FP, Ohashi $\mathrm{H}$. The crystal structure of $\mathrm{CaFe}^{3+} \mathrm{SiAlO}_{6}$ and the crystal chemistry of $\mathrm{Fe}^{3+}-\mathrm{Al}^{3+}$ substitution in calcium Tschermak's pyroxene. Contrib Mineral Petrol. 1986; 92: 530-535. doi: 10.1007/BF00374434.

14. Chukanov NV. Infrared spectra of mineral species. Dordrecht: Springer; 2014. 1726 p. doi: 10.1007/978-94-007-7128-4.

15. Hafner S, Huckenholz H. Mossbauer spectrum of synthetic ferri-diopside. Nat Phys Sci. 1971; 233: 9-11. doi: $10.1038 /$ physci233009a0. 